
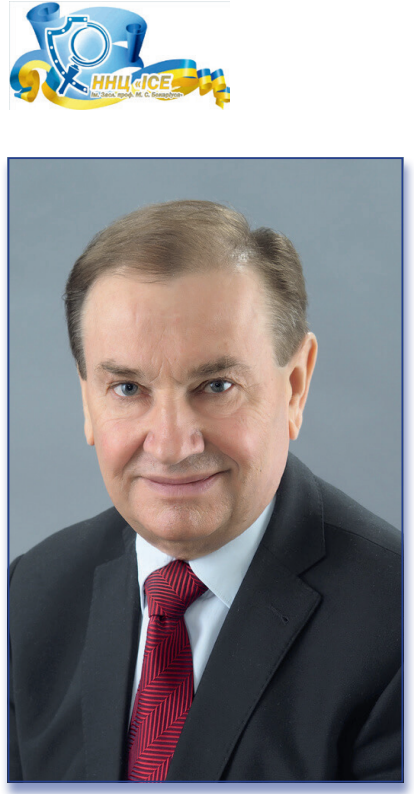

Nechyporuk Mykola

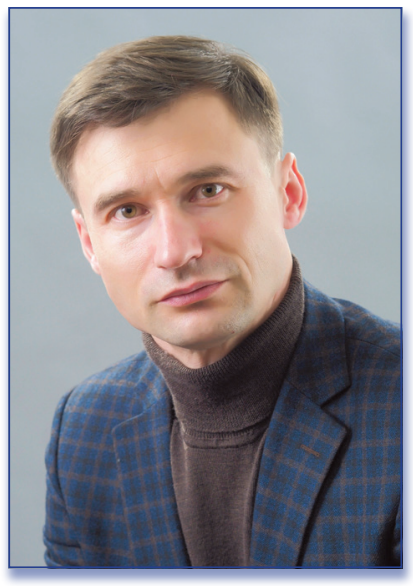

Pavlikov Volodymyr

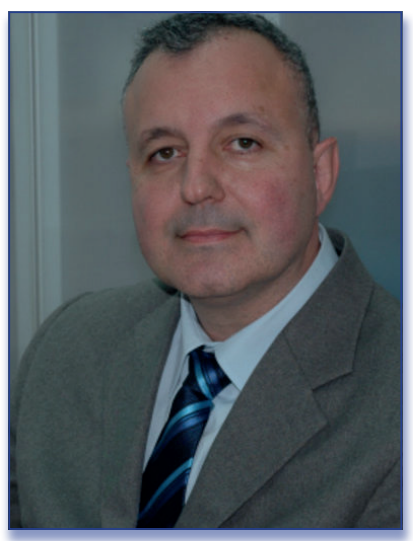

Ivanović Aleksandar
Forensic science posibilities within the framework

of criminal proceedings while aviation accidents (Review article)

DOI: https://doi.org/10.32353/acfs.3.2021.04

UDK $349.85+343.98$

Mykola Nechyporuk,

Doctor of Technology, Professor, Rector of Law Department of National Aerospace University «Kharkiv Aviation Institute " NAU "KhAI", Chkalova Street, 17, Kharkiv 61070, Ukraine ORCID: https://orcid.org/0000-0002-2723-6107

Scopus Author ID: https://www.scopus.com/authid/detail.uri?authorId=57210558126

khai@khai.edu

Volodymyr Pavlikov,

Doctor of Technology, Professor, Vice-Rector for Research of Law Department of National Aerospace University - "Kharkiv Aviation Institute " NAU "KhAI", Chkalova Street, 17, Kharkiv 61070, Ukraine

ORCID: https://orcid.org/0000-0002-6370-1758

Scopus Author ID: https://www.scopus.com/authid/detail.uri?authorId=23397933100 v.pavlikov@khai.edu

Aleksandar Ivanović,

Doctor of Law, Professor,

Director of Forensic Center Montenegro,

Danilovgrad, Montenegro

Nataliia Filipenko,

PhD in Law, Docent, Associate Professor at the Law Department of National Aerospace

University - "Kharkiv Aviation Institute " NAU "KhAI", Chkalova Street, 17, Kharkiv 61070,

Ukraine

ORCID: https://orcid.org/0000-0001-9469-3650

n.filipenko@khai.edu

\section{Forensic science posibilities within the framework of criminal proceedings while aviation accidents (Review article)}

The article analyzes scientific opinions on the content of criminalistics activity of forensic science institutions within the criminal proceedings regarding aviation accidents. The bases of such activity are formulated. Possibility of expanding the mandatory appointment of forensic examinations in criminal proceedings for aviation accidents is being considered. Factual and legal grounds for the appointment and conduct of forensic examination in this case are presented.

Scientifically substantiated recommendations as for directions of counteraction to attacks on objects of aircraft industry are given and the development algorithm of innovations for the needs of law enforcement agencies is offered.

Keywords: criminal proceedings, forensic science, specific expertise, crime counteraction, crime investigation, law enforcement agencies.

Introduction. Efficiency of criminal proceedings implementation mostly depends on the results of expert researches, especially if we talk about the complex process of aviation accident investigation. In turn, the quality of expert researches depends on organization of activities in forensic science institutions regarding creation of effective methods of analysis of different physical evidence obtained at the place of aviation accident. Modern period of the development of legal science in Ukraine is associated with the necessity to solve a wide range of problems, among which a significant place is taken by the issue of study and creative analysis of scientific developments, ways of implementing scientific and technological developments, identification of promising directions in research, etc. 
Analysis of publications where this problem solution is initiated. In a broad sense, scientific papers by many scientists, in particular by A. M. Babenko, O. M. Bandurky, V. S. Batyrhareieva, O. M. Kliuiev, V. M. Kobryn, V. P. Kolmakov, O. M. Lytvynov, M. V. Nechyporuk, Yu. V. Orlov, E. B. Simakova-Yefremian, H. O. Spitsyna, O. O. Tytarenko, V. Yu. Shepitko and others ${ }^{1}$ are dedicated to the possibilities of forensic science within the framework of criminal proceedings. However, most scientists developed one or several sections of the problem under consideration, without solving it in a comprehensive, integrated way.

Aim. The aim of the article is to study possibilities of forensic science within the framework of criminal proceedings while aviation accidents.

Results and discussion. Using special knowledge, employees of forensic science institutions independently or in cooperation with employees from other specialized institutions, law enforcement agencies, doctors can improve methods of expert research and accordingly prevent commission of criminal offenses or ensure its early detection and identification of the offender whereabouts.

In accordance with paragraph 10 of Part 1, Art. 3 of the Criminal Procedural Code of $U_{k r a i n e}{ }^{2}$, a criminal proceeding is a pre-trial investigation and court proceedings or procedural actions in relation to commission of an act stipulated by the Law of Ukraine on Criminal Liability. The whole process of criminal proceedings relates to the establishment and proof of such actual circumstances as the event of a criminal offense (time, place, method and other circumstances of criminal offense commission), guilt of the accused in criminal offense commission, form of guilt, motive and purpose of criminal offense commission; type and amount of damage caused as a result of a criminal offense, as well as the amount of procedural costs, circumstances that affect the severity of committed criminal offense, characterize the identity of the accused, aggravate or mitigate punishments excluding criminal liability or being the basis for closing criminal proceedings, etc.

In most cases, the establishment of the mentioned facts requires research on the basis of specific expertise in the field of science, technology or art. To solve the set tasks, Criminal Procedural Code of Ukraine stipulates the involvement of a forensic expert or a specialist, that is persons who possess scientific, technical or specific expertise and have the right to conduct forensic examinations or participate in other procedural actions and are entrusted to carry out researches on objects, phenomena and process containing information on circumstances of criminal offense commission, as well as provide conclusion or advice on the issues arising while criminal proceedings and relating to the area of their expertise (Art. 69, 71 of the Criminal Procedural Code of Ukraine). Thus, specific expertise in criminal proceedings is used in two forms: in case of experts' involvement while individual investigative (court) proceedings and within the framework of conducting a forensic examination.

In the course of forensic examination, in contrast to other procedural actions, significant facts in a case can be established in the absence of an investigator (or court). This peculiarity enables to explain why the legislator adopted a system of additional procedural guarantees, compliance with which is intended to contribute to a reliable, complete and objective establishment of facts by a forensic expert and to a comprehensive review of his conclusions

Е. g., наприклад, Батиргареєва В. С., Бабенко А. М. Аналіз сучасної криміногенно ситуації в Україні як інформаційна модель для розробки стратегії зменшення можливостей вчинення злочинів. Архів кримінологї̈ та судових наук : наук. журнал / Ред. кол.: О. M. Kliuiev, V. С. Батиргареєва, Г. О. Спіцина та ін. Харків : ХНДІСЕ, 2020. №. 1. С 39-53.; Клюєв О. М. Удосконалення експертного забезпечення правосуддя: теоретичні, правові, та організаційні аспекти. Теорія і практика судової експертизи та криміналістики. Харків : Право, 2019. Вип. 19. С. 102-117; Сімакова-Єфремян Е. Б. Комплексні судовоекспертні дослідження: теорія та практика: монографія. Харків: Право, 165 с.; Mykola Nechyporuk, Volodymyr Pavlikov, Nataliia Filipenko, Hanna Spitsyna, Ihor Shynkarenko Cyberterrorism Attacks on Critical Infrastructure and Aviation: Criminal and Legal Policy of Countering. Integrated Computer Technologies in Mechanical Engineering - 2020. Synergetic Engineering P. 206-220. ISBN 978-3-030-66716-0 ISBN 978-3-030-66717-7 (eBook). URL: https:// doi.org/10.1007/978-3-030-66717-7 та ін.

Кримінальний процесуальний кодекс України. Відомості Верховної Ради України (ВВР), 2013, № 9-10, № 11-12, № 13, ст.88). URL: https:// zakon.rada.gov.ua/laws/show/4651-17\#Text.

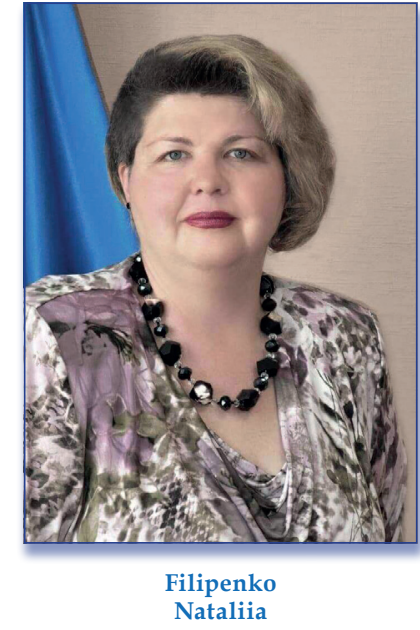

M. Nechyporuk,

V. Pavlikov,

A. Ivanović,

N. Filipenko

\section{FORENSIC SCIENCE}

POSIBILITIES WITHIN THE

FRAMEWORK OF CRIMINAL

PROCEEDINGS WHILE

AVIATION ACCIDENTS

The article analyzes conceptual framework for specific expertise use while conducting forensic examinations related to aviation accidents. Foundations of such activities have been developed. In particular, it is stressed that effective implementation of criminal proceedings depends to a greater extent on the results of expert researches, especially if it is a complex process of aviation accident investigation. Similarly, the quality of expert researches depends on organization of research institutes activity regarding creation of effective methodologies for the analysis of different physical evidence obtained at the aviation accident scene. By using specific expertise, employees of forensic institutions independently or jointly with employees of other specialized institutions, law enforcement agencies, specialists-doctors can advance methods of expert research and, consequently, combat criminal offenses or ensure timely detection of the offender whereabouts.

The possibility of expanding the compulsory appointment of forensic examinations in aviation accident criminal proceedings is being considered. Factual and legal grounds for the appointment and conduct of a forensic examination in this case are outlined. 


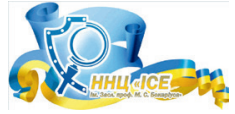

Scientifically

substantiated recommendations on directions of counteraction to attacks on the aviation industry facilities are suggested, as well as the algorithm for developing innovations for the needs of law enforcement agencies is proposed.

It is emphasized that the use of forensic science possibilities within the framework of a criminal proceeding related to aviation accidents is quite influential, since it helps to perform a multidisciplinary professional analysis of evidence, facilitate organization of forensic experts' work, protect the rights of citizens and contribute to fulfillment of justice tasks in general.

Keywords: criminalistics, forensic science, criminal proceeding, aviation accidents, forensic institutions, law enforcement agencies.

\section{М. В. Нечипорук \\ В. В. Павліков, \\ А. Іванович \\ Н. С. Філіпенко}

МОЖЛИВОСТІ СУДОВОЇ ЕКСПЕРТИЗИ В МЕЖАХ КРИМІНАЛЬНОГО ПРОВАДЖЕННЯ ЗА ФАКТАМИ АВІАКАТАСТРОФ

У статті проаналізовано концептуальні основи використання спеціальних знань при проведенні судових експертиз за фактами авіакатастроф. Сформульовано основи такої діяльності. Зокрема зазначено, що Ефективність здійснення кри мінального провадження більшою мірою залежить від результатів експертних досліджень, особливо якщо йдеться про складний процес розслідування авіакатастроф. Так само якість експертних досліджень залежить від організації діяльності науково-дослідних установ щодо створення ефективних методик аналізу різних речових доказів, отриманих 3 місця авіатрощі. Використовуючи спеціальні знання, працівники експертних установ самостійно чи у співпраці зі співробітниками інших спеціалізованих інституцій, правоохоронних органів, фахівців-медиків можуть удосконалювати методики експертного дослідження та, врешті-решт, перешкоджати вчиненню кримінальних правопорушень або забезпечити оперативне виявлення і знаходження правопорушника.

Розглядається можливість розширення обов'язкового призначення судових експертиз у кримінальному провадженні за авіаційними аваріями. Викладено фактичні та правові підстави для призначення та проведення судової експертизи у цій справі.
Forensic science posibilities within the framework

of criminal proceedings while aviation accidents (Review article)

by investigators and court. Forensic examination should be appointed only when it is really needed, when it is impossible to establish the truth in a case without answers to certain questions provided by a forensic expert. It is the study of aviation accident causes that provides sufficient grounds for attracting forensic experts, specialists, medical examiners.

In addition, the task of crime counteraction and offenses prevention while conducting specific types of forensic examinations is stressed in the Instructions on the appointment and conduct of forensic examinations and expert researches and in the Scientific and methodical recommendations concerning preparation and appointment of forensic examinations and expert researches. The obligation to establish causes and conditions of criminal offense commission is also directly stipulated by the procedure for conducting a forensic examination on circumstances and mechanism of man-made explosions, forensic biological analysis, etc. In the event of an aviation accident, a multidisciplinary forensic examination, forensic medical examination and DNA analysis of victims' remains are appointed for a comprehensive research on bodies of crew members, passengers, different objects, which condition can provide information about the performance and nature of the crew activities during an accident, establishment of causes and nature of aircraft damages, amount of damage and compliance with the rules of international flights and other factual material contributing to the disclosure of a criminal event.

Since 1951, the International Civil Aviation Organisation (ICAO) has published international standards and recommended practices (SARPS) to its member states that air crashes and serious incidents should be investigated in the same way (ICAO, 2016). In Europe, this was mandated by the European Parliament through EU996/2010 (European Union, 2010). Air accident investigation is a complex task that draws upon a broad range of skills. Although many of the component parts of the task are not inherently difficult, it is the nature of accidents that creates the potential for great complexity (Strauch, 2016). Air accidents are unscheduled, destructive and may lead to loss of life. They are often highly visible, shocking and can become politically sensitive ${ }^{3}$. The accident investigation process is laid out by the standards and recommended practices in an international agreement called Annex 13 of the Convention on International Civil Aviation. That document outlines the process of gathering and analyzing information and drawing conclusions - including determining the causes of a crash and making safety recommendations ${ }^{4}$.

In 2020, more people died in aviation accidents than in 2019, though the number of flights rapidly declines due to the pandemic. Last year, 299 people died, and in 2019: 2575. Unfortunately, Ukrainian society was shocked by a series of aviation accidents happened in our country or with participation of our citizens last year. Thus, on the night of January 8, 2020, the Boeing-737 plane of Ukraine International Airlines crashed shortly after departure from Imam Khomeini International Airport situated in the outskirts of Tehran. There were 167 passengers and 9 crew members on board, all of them died. Among the victims of the crash: 11 Ukrainians. There were also 82 citizens of Iran, 63: Canada, 10: Sweden, 4: Afghanistan, as well as 3 citizens of Germany and the United Kingdom. On January 11, Iran acknowledged that the Boeing plane was inadvertently shot down by Iranian missile since it had been perceived as an enemy target. Ukrainian law enforcement agencies conducted more than 200 procedural and investigative actions in the case of Ukrainian plane crash near Tehran, and sent 18 requests for international legal assistance ${ }^{6}$ to other countries.

What do aircraft accident investigators do and what makes them good at it? Developing a competency framework for investigators using grounded theory. URL: https://www. sciencedirect.com/science/article/pii/S0925753517306409.

4 Here's how airplane crash investigations work, according to an aviation safety expert. URL: https://theconversation.com/heres-how-airplane-crash-investigations-work-according-to-anaviation-safety-expert-113602.

Кількість жертв авіакатастроф у 2020 році зросла попри Covid-19. URL: https://www. bbc.com/ukrainian/news-55515388.

Літак МАУ розбився в Ірані: понад 170 загиблих. URL: https://www.dw.com/uk/літакмау-розбився-в-ірані-понад-170-загиблих/а-51925157. 
On September 25, 2020, the An-26 plane crashed near Chuhuiv (Kharkiv region) around 20:00. The aviation accident happened during scheduled training flights, when the plane landed at the airdrome of the military unit in Chuhuiv. There were 27 people on board (20 cadets and seven officers of Ivan Kozhedub Kharkiv University of Air Force). 25 people died right there, two cadets were hospitalized. On the morning of September 26, one of the hospitalized died at the hospital. In view of the aviation accident, criminal proceedings were initiated under Article 416 (violation of flight rules and preparation for them which resulted in a crash and serious consequences) of the Criminal Code of Ukraine ${ }^{7}$. It is in such high-profile cases of aviation accidents that all possibilities of forensic science are used.

As scientists and experts-practitioners rightly note ${ }^{8}$, at the beginning of an investigation, inspection of plane wreckage at the scene is carried out to get a general understanding of circumstances occurred while aviation accident. At the same time, initial impact point is set, the flight path is followed by searching for marks on the ground and objects in the surrounding environment. The possible trajectory of an airliner, the angle and speed of landing, controllability and the presence of destruction in the structure before collision are determined. The whole area with overall setting of fragments and their condition is photographed. Individual sections and structural elements are photographed, drawing particular attention to devices, position of control sticks in the cockpit, settings, autopilot installation, position of fuel valves, switches, position of control surfaces, suspicious breakage or deflections, position of propellers, thrust levers in the cockpit and on the engine, fire damage, traces left on the ground when falling, position of airliner seats and seat belts.

It is highly useful to implement unmanned aerial vehicle (UAVs) or so called drones at the scene which provide researchers with a number of opportunities and benefits, for example: rapid deployment (unlike search and rescue services, drones can be deployed within minutes after arrival at the scene of an aviation accident); full control (the operator controls trajectory and angle of view, so he can place the camera in an optimal position; high quality shooting (modern UAVs are equipped with high-quality cameras with image stabilization); easy restart when it is needed to take additional shots; it can work in conditions of poor visibility and low clouds. What is more, unmanned aerial vehicles can be kept close to trees and debris to obtain close-up images without changing their location. In addition, modern UAVs are devices of the so-called "multi-use profile", which can be very quickly reprogrammed from performing a single function (e.g., environmental research) to fulfilling the needs of working in extreme conditions at aviation accident scene ${ }^{9}$.

After, with the involvement of a forensic expert, the scheme of location of fragments, cargo, bodies of dead and alive, marks at the scene and sites where photos were taken, is created. Meanwhile, special focus should be made on the point of contact with ground, length and depth of sliding traces, obstacles (trees, shrubs, etc.), position of the main fragment (fuselage), distance, direction, relative position of main details, position of other details, direction of flight, etc. On the basis of obtained data, it is possible to create a 3-D model of an accident site.

Fragments are searched throughout the whole area. If it is big, several search groups are formed. Fragments are left untouched until photographing and drawing up a scheme. The following is kept for testing: parts having caused doubts as to the quality of casting, heat treatment, compliance with specifications; parts that have design and manufacturing defects; pipelines, connecting control units, parts with insufficient fastening, prone to vibration; torn oil fuel wires, etc. For example, the wreckage trail of the Pan Am Boeing

Катастрофа літака ЗСУ під Харковом. URL: https://www.ukrinform.ua/tag-katastrofalitaka-zsu-pid-harkovom

Accident investigation. https://www.ecac-ceac.org/accident-investigation; Accident Investigation Techniques - Best Practices. URL: https://www.skybrary.aero/index.php/ Accident_Investigation_Techniques___Best_Practices; Investigation Methodology. URL: https://www.skybrary.aero/index.php/_/nvestigation_Methodology.

Беспилотные авиационные комплексы для решения экологических задач / В. Н. Кобрин, H. В. Нечипорук, Н. В. Кобрина. Екологічна безпека. 2014. Вип. 2. С. 43-50. URL: http:// nbuv.gov.ua/UJRN/ekbez_2014_2_9.

Надано науково-обгрунтовані рекомендації щодо напрямів протидії атакам на об'єкти авіаційної промисловості та запропоновано алгоритм розробки інновацій для потреб правоохоронних органів.

Підкреслено, що використання можливостей судової експертизи в межах кримінального провадження за фактами авіакатастроф досить потужні, оскільки надають змогу здійснення всебічного фахового аналізу доказів, поліпшення організації роботи експертів, захисту прав громадян і сприяють виконанню завдань правосуддя в цілому.

Ключові слова: криміналістика, судова експертиза, кримінальне провадження, авіакатастрофа, судово-експертні установи, правоохоронні органи.

\section{Н. В. Нечипорук,}

В. В. Павликов,

А. Иванович,

Н. Е. Филипенко

ВОЗМОЖНОСТИ СУДЕБНОЙ ЭКСПЕРТИЗЫ ПРИ ОСУЩЕ-

СТВЛЕНИИ УГОЛОВНОГО ПРОИЗВОДСТВА ПО ФАКТАМ АВИАКАТАСТРОФ

В статье проанализировань конщептуальные основы использования специальных знаний при проведении судебных экспертиз по фактам авиакатастроф. Сформулированы основы такой деятельности. В частности отмечено, что эффективность осуществления уголовного производства в большей степени зависит от результатов экспертных исследований, особенно если речь идет о сложном процессе расследования авиакатастроф. Также качество экспертных исследований зависит от организации деятельности научноисследовательских учреждений по созданию эффективных методик анализа вещественных доказательств, полученных с места крушения авиатранспорта. Используя специальные знания, работники экспертных учреждений самостоятельно или в сотрудничестве с работниками других специализированных учреждений, правоохранительных органов, специалистов-медиков могут усовершенствовать методики экспертного исследования и эффективно противодействовать совершению уголовных проступков, обеспечить скорейшее выявление и зобличения правонарушителя.

Рассматривается возможность расширения обязательного назначения судебных экспертиз в уголовном производстве по авиакатастрофам. Изложены правовые основания для 


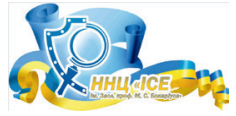

назначения и проведения судебной экспертизы по таким уголовным делам.

Изданы научно-обоснованные рекомендации по направлениям противодействия атакам на объекты авиационной промышленности и предложен алгоритм разработки инноваций для нужд правоохранительных органов.

Подчеркивается, использование возможностей судебной экспертизы в рамках уголовного производства по фактам авиакатастроф достаточно весомое, поскольку предоставляет возможность осуществления всестороннего профессионального анализа доказательств, улучшения организации работы экспертов, защиты прав граждан и способствует обеспечению правосудия в целом.

Ключевые слова: криминалистика, судебная экспертиза, уголовное производство, авиакатастрофа, судебно-экспертные учреждения, правоохранительные органы.

M. Nechyporuk, V. Pavlikov,

A. Ivanović, N. Filipenko

MÖGLICHKEITEN DER

FORENSISCHEN EXPERTISE

IM RAHMEN DES

STRAFVERFAHRENS IN

BEZUG AUF DIE FAKTEN DER

FLUGZEUGABSTÜRZE

In der Abhandlung analysiert man die konzeptionellen Grundlagen für die Verwendung von Spezialwissen bei der Durchführung forensischer Untersuchungen $\mathrm{zu}$ den Fakten von Flugzeugabstürzen. Die Grundlagen dieser Aktivität werden formuliert. Insbesondere wird darauf hingewiesen, dass die Wirksamkeit der Ausführung vom Strafverfahren in ausgedehnterem Maße von den Ergebnissen der Expertenforschung abhängt, besonders wenn es um den komplizierten Prozess der Untersuchung von Flugzeugabstürzen geht. Die Qualität der Expertenforschung hängt auch von der Organisation der Aktivitäten von Forschungseinrichtungen in Bezug auf die Entwicklung der wirksamen Methoden zur Analyse verschiedener Beweisgegenstände $a b$, die vom Ort des Flugzeugabsturzes erhalten wurden. MitSpezialwissen können die Mitarbeiter von Experteninstitutionen allein oder in Zusammenarbeit mit Mitarbeitern anderer spezialisierter Institutionen, Rechtsschutzorgane und medizinischer Spezialisten die Methoden der Expertenforschung verbessern und letztendlich die Begehung von Kriminalverbrechen verhindern oder die sofortige
Forensic science posibilities within the framework

of criminal proceedings while aviation accidents (Review article)

747 that exploded over the town of Lockerbie in 1988 was $130 \mathrm{~km}$ long (AAIB, 1990). Each piece of wreckage had to be cataloged and its location documented ${ }^{10}$.

Assessing the learning value of an occurrence prior to deployment or evidence collection is difficult. Some investigation agencies have taken the decision not to investigate particular event types. For example, the Australian Transport Safety Bureau (ATSB) does not investigate all small air accidents even if there was a fatality involved due to the large territory (Australian Transport Safety Bureau, 2017). Other investigation agencies accept that field deployment provides opportunity for maintaining currency, even if no significant safety -lessons are anticipated or reported. Where a national investigation agency makes a decision not to investigate, it is likely that other stakeholders: the aircraft operator, airport, manufacturer or insurer will conduct their own ${ }^{11}$

Later all obtained materials are transported to a forensic science institution where all main forensic examinations will be conducted in specialized laboratories. To carry out a more thorough study of the characteristics of each specific aviation accident, the entire fuselage of an airliner is reconstructed. Laboratory tests are not limited to standard tests. Every effort should be made to perform tests by fully recreating operational capabilities of elements in emergency conditions. Parts along with elements connected with them are taken for research, because oftentimes reasons for defect formation could be found within connecting elements. Forensic experts draw special attention to the search for defects that are the result of parts wear, metal fatigue, structural defects, negligence during installation or operation of an airliner.

The majority of aviation accidents are accompanied by devastation of bodies of the dead and airplane equipment. Moreover, usually there are no witnesses who notice the moment of an airliner falling. Therefore, in addition to studying the information on records in aircraft emergency recorders, it is crucial to study various objects that remain at aviation accident site. Such research can only be carried out by conducting a multidisciplinary forensic examination ${ }^{12}$.

Trace evidence analysis of objects, analysis of speech patterns of the crew and sound effects arising in emergency conditions, as well as experimental modeling of emergencies are the most effective while conducting forensic examinations. Trace evidence analysis is aimed at identifying and assessing the significance of damage formed in objects as a result of their mutual collision, or changes in the nature of objects under the influence of melting, burning, fluid seepage, etc.

Thanks to information obtained during trace evidence analysis (peculiarities of damage and marks on the body and clothes), it may be assumed whether a crew member was fastened with seat belts. If seat belts are fastened at the time of collision, they may be damaged or torn at the points of attachment to a chair, often combined with deformation of lock parts.

Traces left on the helmet often carry information about the direction of force impact and implicitly about the position of a pilot's head at the time of collision. Examining paint marks, dents and grooves on a helmet, it is possible to identify a part hit by a pilot's head. This, in turn, allows you to identify his posture and establish the mechanism of injury. Traces on flight helmets enable to establish the sequence of their formation, sequence of force impacts, etc. better than on other equipment. For example, if the head hits the cockpit parts when shaking in the air and dents are formed on the helmet, then newly formed traces are located only on protruding parts of existing damage during subsequent collision or explosion, not reaching their recesses. This indicates that dents are formed while aviation accident.

10 What do aircraft accident investigators do and what makes them good at it? Developing a competency framework for investigators using grounded theory. URL: https://www. sciencedirect.com/science/article/pii/S0925753517306409.

11 What do aircraft accident investigators do and what makes them good at it? Developing a competency framework for investigators using grounded theory. URL: https://www. sciencedirect.com/science/article/pii/S0925753517306409.

12 Accident Investigation Techniques - Best Practices. URL: https://www.skybrary.aero/index. php/Accident_Investigation_Techniques_-_Best_Practices. 
Suitability of equipment, considering flight conditions, can be established even by individual pieces of clothing and equipment. If such fragments by their localization correspond to the same place where clothes and equipment on a pilot can be found, and the nature of available traces and damage (tears, liquid spots) is identical, a conclusion may be drawn regarding the fact that at the moment of force impact all these fragments are placed in layers on a pilot. In other words, it can be determined what items of clothing and equipment are worn by him.
Aufdeckung und Auffindung des Straftäters gewährleisten.

Die Möglichkeit der Ausweitung der obligatorischen Anordnung eines Sachverständigengutachtens in Strafverfahren wegen Flugunfällen wird behandelt. Die tatsächlichen und rechtlichen Gründe für die Anordnung und Durchführung einer

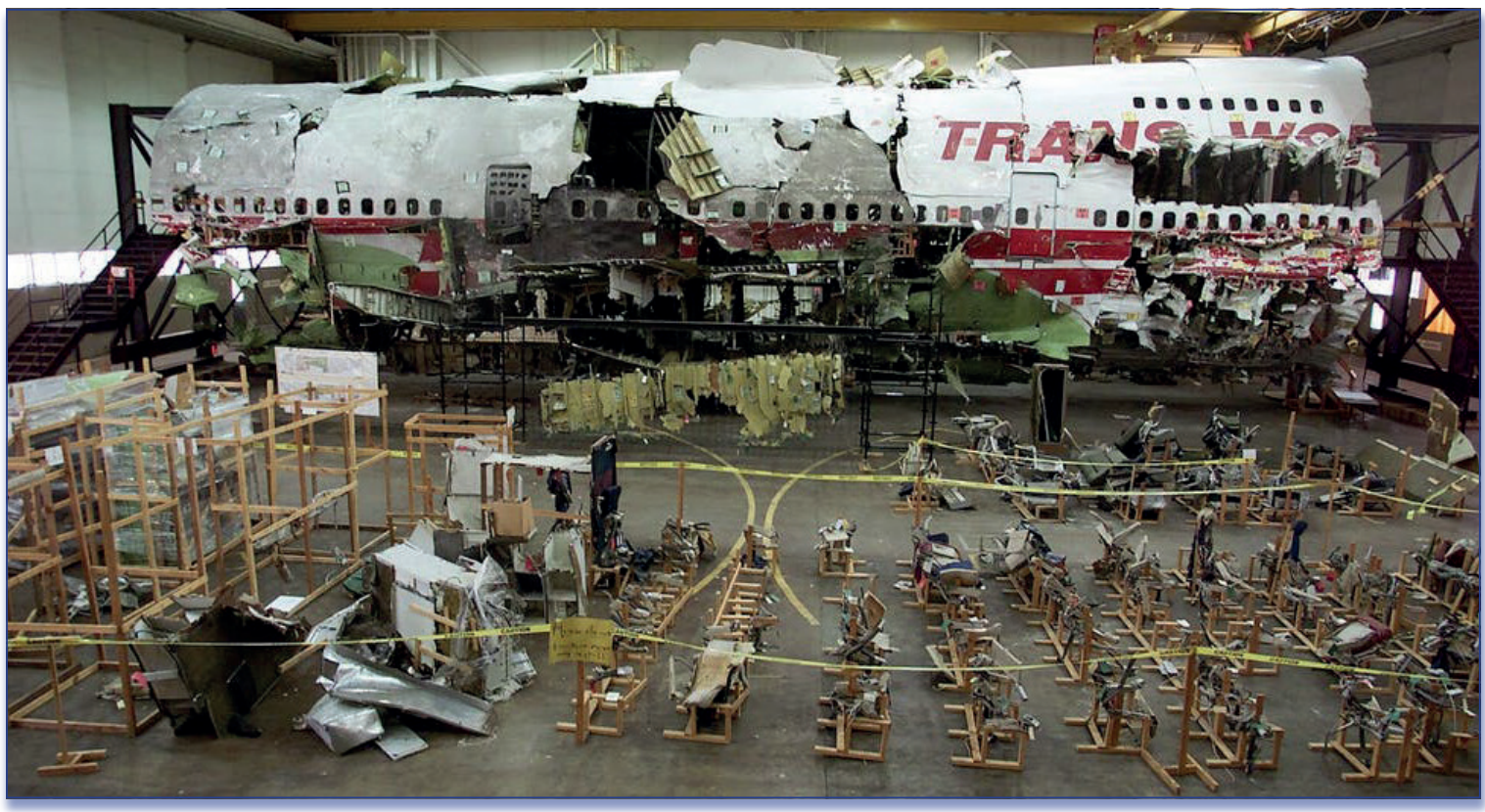

Investigators reconstructed almost the entire fuselage of the TWA Flight 800 aircraft after its crash in Long Island Sound in 1996. AP Photo/ Ed Betz

Damage and marks left on shoes, gloves, protective or pressure helmets, headsets or helmets are of great importance for making conclusions as to a pilot's working posture. In some cases, damage and marks left on other parts of equipment may be significant. Damage to clothing and equipment in its shape and location are combined with injuries to the body or limbs. The position of a pilot's limbs during an accident is an important point for drawing conclusion about his activity or inactivity while emergency. For example, the establishment of the fact of grasping chassis control levers or flaps with the left hand indicates active actions of a pilot, his attempts to control the process.

If at the time of a devastating collision a pilot's feet are on control pedals, stamped footprint may be left on soles of shoes copying a size and sometimes ridged surface of pedals. At the same time, a foot and shoes are strongly bent downwards in this area, causing skin tear in the upper part of a shoe, combined with bone fractures and destruction of foot soft tissues. If the sole is made of natural rubber or other elastic material, there may be no clear traces, but you can examine little cracks in the sole, tearing-off of its individual pieces from the edges in the area that came into contact with the control pedal.

Forensic phonoscopic examination and linguistic analysis are equally important helping to obtain information from the so-called "black boxes" of an airplane. There are two kinds. The flight data recorders keep track of flight parameters such altitude, heading, instrument readings, power settings and flight control inputs. The cockpit voice recorders store all communications with the aircraft, including from air traffic controllers, and record any forensischen Untersuchung in diesem Fall werden dargelegt.

Die wissenschaftlich-begründeten Empfehlungen $\mathrm{zu}$ den Richtungen des Widerstandes gegen Angriffe auf Objekte der Luftfahrtindustrie werden auseinandergesetzt und der Algorithmus zur Entwicklung von Innovationen für die Bedürfnisse von Rechtsschutzorganen wird angeboten.

Es wurde betont, dass die Verwendung der Möglichkeiten der forensischen Expertise in Strafverfahren in Bezug auf die Fakten von Flugzeugabstürzen sehr effektiv ist, denn es ermöglicht, die umfassende professionelle Analyse von Beweismitteln $\mathrm{zu}$ machen, die Organisation der Arbeit von Experten zu verbessern, die Rechte der Bürger zu schützen, und fördert die Durchführung von Aufgaben der Justiz im Allgemeinen.

Schlüsselwörter: Kriminalistik forensische Expertise, Strafverfahren, Flugzeugabsturz, forensische Einrichtungen, Rechtsschutzorgane. 
Forensic science posibilities within the framework

of criminal proceedings while aviation accidents (Review article)

conversations among cockpit occupants and other audible cockpit sounds for the two hours leading up to the crash. All that information lets analysts reconstruct, and even create video simulations of the last moments of the plane's flight ${ }^{13}$.

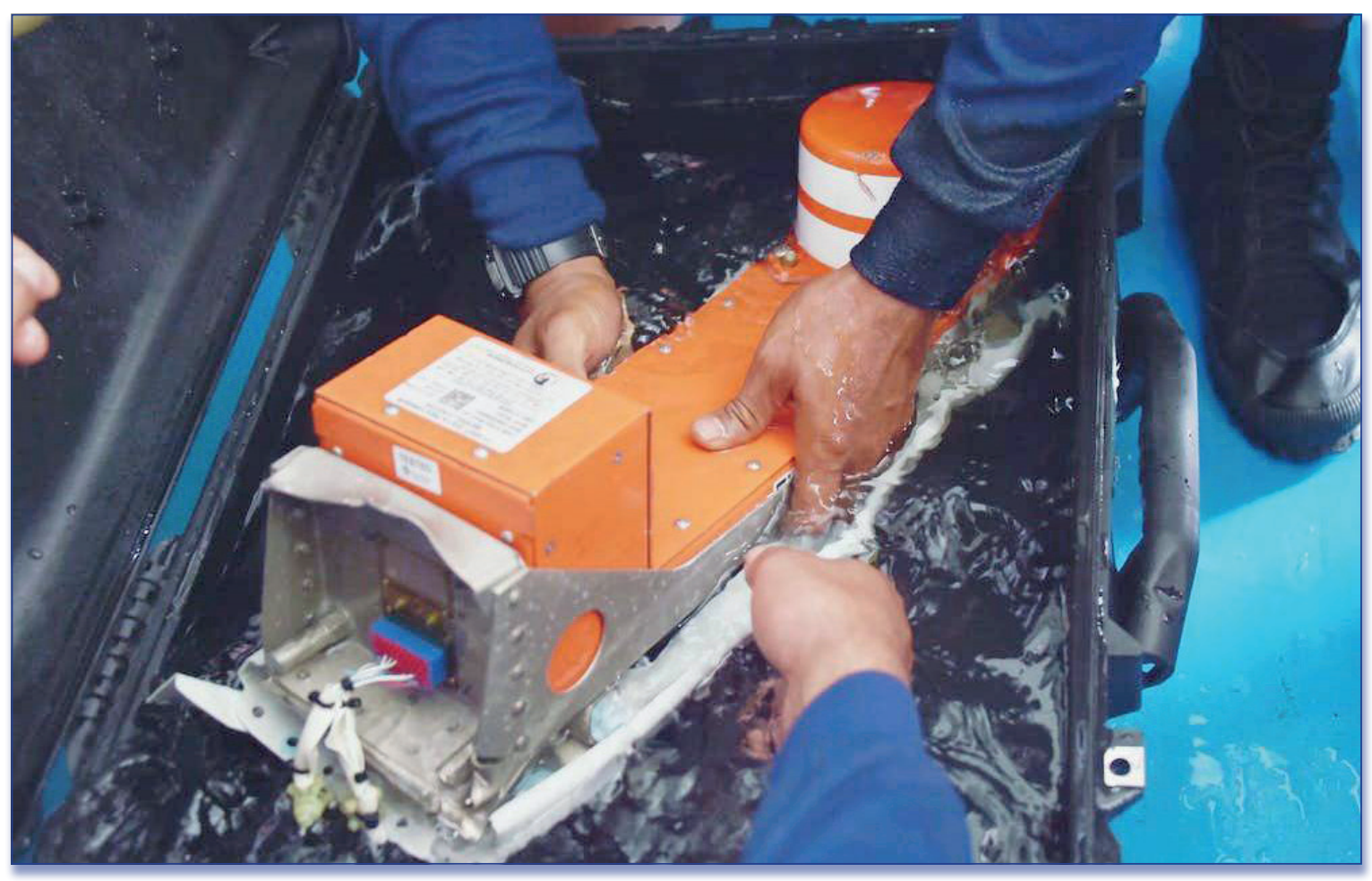

An aircraft's 'black box' is really bright orange. AP Photo/Adek Berry

Furthermore, study of speech and sound information recorded in emergency conditions of flight is aimed at obtaining information about changes in a pilot's condition while flight, factors affecting his performance,

M. Nechyporuk, V. Pavlikov, A. Ivanović, N. Filipenko

POSSIBILITÉS D'EXPERTISE JUDICIAIRE DANS LE CADRE DE LA PROCÉDURE PÉNALE SELON LES FAITS D'ACCIDENT AÉRIEN

L'article analyse la base conceptuelle de l'utilisation de connaissances spéciales pendant dans la réalisation d'analyse scientifique de cas sur les faits des accidents d'avion. Les bases d'une telle activité sont formulées. En particulier, il est à noter que l'efficacité des procédures pénales dépend dans une plus large mesure des résultats de la recherche d'experts, en particulier lorsqu'il s'agit du processus complexe d'enquête sur les accidents aériens. De même, la qualité de la recherche d'experts dépend de l'organisation des instituts de recherche pour créer as well as clarification of certain circumstances occurred during an emergency. This method is based on physical indicators of changes in frequency spectrum and characteristics of the same words and phonemes uttered on the radio, as well as individual sound and noise effects. Magnetic recordings of radio exchange are studied, given peculiarities of each radio station. It is known that with the increase of emotional tension, speech changes. In particular, a so-called shift to the right in frequency takes place in spectral characteristics of individual words or phonemes, i.e. towards higher frequencies (similar changes in speech can be observed in everyday life: voice becomes higher when frightened, and bass notes predominate in a calm state). Also, when flight conditions worsen, speech tempo in the radio exchange may change. Sometimes there are warnings, unnecessary pauses, rapid speech, which also indicate changes in the human condition.

The establishment of the fact of audible alarms operation in emergency conditions can facilitate the identification of reasons contributed to an emergency. When mixing with the general background noise in a cockpit, these sounds are difficult to detect by ear. Since the frequency spectrum of such signals differs from other noises, they can be detected by using frequency filters and then listened to in a relatively pure form. In this way, for

13 Here's how airplane crash investigations work, according to an aviation safety expert. URL: https://theconversation.com/heres-how-airplane-crash-investigations-work-according-to-anaviation-safety-expert-113602. 
example, the sound of a siren signaling depressurization of the cockpit, etc. can be detected.

In parallel with forensic examinations, forensic medical examinations are carried out. As noted by forensic experts ${ }^{14}$, they urgently have to address the following main issues related to the condition and performance of crew members, possible actions of each of them in emergency conditions and a number of other data: what kind of damage crew members received, what is the mechanism of its formation and which cockpit parts formed it; which of the injuries are lifelong; what external factors affected the crew in emergency conditions (fire, smoke, combustible and lubricating oils, cold, pressure differentials, overload); whether alcohol, carbon monoxide are contained in blood and tissues of the dead; cause and time of death; who of the crew members owns detected remains or objects of equipment and uniform; whether the dead suffered from any diseases and how it affected their performance during flight; what was the posture of each crew member at the final moment of an emergency (position of torso, arms, legs and head); where each crew member was; which levers, cranes and toggle switches each crew member hit at the moment of collision, explosion, etc.; what was the equipment of each crew member; what was the condition of crew members while an emergency (whether they were alive, active or passive, able to work), etc.

Currently, molecular genetic research is of great importance. In the course of identification, DNA samples are taken from the dead: fragments of muscle tissue, bone tissue and teeth fragments (DNA is best protected from external influences in teeth parts). DNA analysis of remains of aviation accident victims is carried out by comparing their genotypes with the genetic material of victims' close relatives. Victims' fingerprints and dental records are also studied. Besides, medical examiners receive personal belongings of victims, for example combs or toothbrushes containing samples of their DNA. But data obtained with their help cannot always be used: sometimes it is impossible to identify who was the owner of the object and whether it was used by other people.

However, research on DNA of aviation accident victims is strongly influenced by several factors. The scarcity of analyzable DNA may also be related to its degradation, which depends on the quality of the remains, related to the circumstances of the catastrophe, to the time elapsed since the victim's death and to the environmental conditions. The degree of degradation also depends on the analyzed tissue; for example, DNA from bones is usually less degraded than that from blood or soft tissues; DNA from blood is less degraded than that from saliva etc. (Dixon et al. 2006). If DNA degradation is very serious, it may present a serious challenge to DVI in an open type of a catastrophe. An inverse relation between the degradation and the length of DNA sequence that can be successfully and reproducibly analyzed influences the choice of DNA profiling technology and of markers to be analyzed (Dixon et al. 2006) $)^{15}$.

Conclusions. Summarizing the above, it could be emphasized that possibilities of forensic science in criminal proceedings while aviation accidents are extremely powerful, since they ensure a multidisciplinary professional analysis of evidence, improve the organization of forensic experts' work, protect citizens' rights and promote justice in general.

\section{References}

Accident Investigation Techniques - Best Practices. URL: https://www.skybrary.aero/ index.php/Accident_Investigation_Techniques_-_Best_Practices [in English].

An UIA plane crashed in Iran, killing more than 170 people. URL: https://www. dw.com/uk/литак-мау-разбился-в-ірани-понад-170-загиблих/а-51925157 [in Ukrainian].

${ }_{14}$ Here's how airplane crash investigations work, according to an aviation safety expert. URL: https://theconversation.com/heres-how-airplane-crash-investigations-work-according-to-anaviation-safety-expert-113602.

15 Ewa Ziętkiewicz, Magdalena Witt, Patrycja Daca, Jadwiga Żebracka-Gala, Mariusz Goniewicz, Barbara Jarząb,Michał Witt Current genetic methodologies in the identification of disaster victims and in forensic analysis. URL: https://www.ncbi.nlm.nih.gov/pmc/articles/ PMC3265735

des méthodes efficaces d'analyse de diverses preuves physiques obtenues sur le lieu de l'accident aérien. En utilisant des connaissances spéciales, les employés d'institutions expertes seuls ou en coopération avec les employés d'autres institutions spécialisées, les services répressifs, les professionnels de la santé peuvent améliorer les méthodes de recherche d'experts et en fin de compte empêcher la commission d'infractions pénales ou assurer une détection rapide du délinquant.

La possibilité d'étendre l'administration obligatoire des analyses scientifiques de cas dans les procédures pénales pour les accidents d'aviation est à l'étude. Les fondements factuels et juridiques de la nomination et de la réalisation d'analyse scientifique de cas dans cette affaire sont exposés.

Les

recommandations scientifiquement étayées sur les directions de la lutte contre les attaques contre les objets de l'industrie aéronautique sont données et l'algorithme de développement d'innovations pour les besoins des forces de l'ordre est proposé.

On a fait remarquer que l'utilisation des possibilités d'analyse scientifique de cas dans les procédures pénales sur les faits des accidents aériens est assez puissante, car elles permettent une analyse professionnelle complète des preuves, améliorant l'organisation des experts, protégeant les droits des citoyens et promouvant la justice en général.

Mots-clés: criminalistique, analyse scientifique de cas, poursuites pénales, accident aérien, institutions forensiques, forces de l'ordre. 
Forensic science posibilities within the framework

of criminal proceedings while aviation accidents (Review article)

Funding

This research did not receive any specific grant from funding agencies in the public, commercial, or not-for-profit sectors.

\section{Disclaimer}

The funders had no role in the study design, data collection and analysis, decision to publish, or preparation of the manuscript.

\section{Contributors}

The authors contributed solely to the intellectual discussion underlying this paper, case-law exploration, writing and editing, and accept responsibility for the content and interpretation.

\section{Declaration of Competing} Interest

The authors declare that they have no conflict of interest.
Batyrgareieva, V. S. \& Babenko, A. M. (2020) Analiz suchasnoyi kryminohennoyi sytuatsiyi v Ukrayini yak informatsiyna model' dlya rozrobky stratehiyi zmenshennya mozhlyvostey vchynennya zlochyniv (Eng. Analysis of the current criminogenic situation in Ukraine as an information model for developing a strategy to reduce the possibility of committing crimes). Arkhiv kryminolohiyi ta sudovyh nauk : nauk. zhurnal / Red. kol.: O. M. Kliuiev, V. S. Batyrhareyeva, H. O. Spitsyna ta in. Kharkiv : KHNDISE, 2020. No. 1. P. 39-53 [in Ukrainian].

The Criminal Procedural Code of Ukraine (Vidomosti Verkhovnoi Rady Ukrainy (VVR). 2013, № 9-10, № 11-12, № 13, p. 88). URL: https://zakon.rada.gov.ua/laws/ show/4651-17\#Text [in Ukrainian].

Ewa Ziętkiewicz, Magdalena Witt, Patrycja Daca, Jadwiga Żebracka-Gala, Mariusz Goniewicz, Barbara Jarząb, Michał Witt Current genetic methodologies in the identification of disaster victims and in forensic analysis. URL: https://www.ncbi. nlm.nih.gov/pmc/articles/PMC3265735 [in English].

Here's how airplane crash investigations work, according to an aviation safety expert. URL: https://theconversation.com/heres-how-airplane-crash-investigationswork-according-to-an-aviation-safety-expert-113602. [in English].

Investigation Methodology. URL: https://www.skybrary.aero/index.php/ Investigation_Methodology. [in English].

Katastrofa litaka ZSU pid Kharkovom (Eng. Ukrainian Armed Forces plane crash near Kharkiv). URL: https://www.ukrinform.ua/tag-katastrofa-litaka-zsu-pidharkovom Kil'kist' zhertv aviakatastrof u 2020 rotsi zrosla popry Covid-19. URL: https://www.bbc.com/ukrainian/news-55515388 [in Ukrainian].

Kil'kist' zhertv aviakatastrof u 2020 rotsi zrosla popry Covid-19 (Eng. The number of victims of aviation accidents in 2020 has increased despite Covid-19.) URL: https:// www.bbc.com/ukrainian/news-55515388 [in Ukrainian].

Kliuiev, O. M. (2019) Udoskonalennya ekspertnoho zabezpechennya pravosuddya:teoretychni, pravovi, ta orhanizatsiyni aspekty (Eng. Improving the forensic expert support of justice: theoretical, legal and organizational aspects). Teoriya i praktyka sudovoyi ekspertyzy ta kryminalistyky. Kharkiv : Pravo, 2019. Vyp. 19. S. 102-117 [in Ukrainian].

Kobrin, V. N. \& Nechyporuk. N. V. \& Kobrina. N. V. (2014) Bespylotnye avyatsyonnye kompleksy dlya reshenyya ékolohycheskykh zadach (Eng. Unmanned aerial systems for solving environmental tasks). Ekolohichna bezpeka. 2014. Vyp. 2. S. 43-50. URL: http://nbuv.gov.ua/UJRN/ekbez_2014_2_9 [in Russian].

Mykola Nechyporuk, Volodymyr Pavlikov, Nataliia Filipenko, Hanna Spitsyna, Ihor Shynkarenko (2020) Cyberterrorism Attacks on Critical Infrastructure and Aviation: Criminal and Legal Policy of Countering. Integrated Computer Technologies in Mechanical Engineering - 2020. Synergetic Engineering P. 206220. ISBN 978-3-030-66716-0 ISBN 978-3-030-66717-7 (eBook). URL: https://doi. org/10.1007/978-3-030-66717-7 [in English].

Simakova-Yefremian, E. B. (2016) Kompleksni sudovo-ekspertni doslidzhennya: teoriya ta praktyka (Eng. Multidisciplinary forensic researches: theory and practice): monohrafiya. Kharkiv : Pravo, 2016. 456 p. [in Ukrainian].

What do aircraft accident investigators do and what makes them good at it? Developing a competency framework for investigators using grounded theory. URL: https://www.sciencedirect.com/science/article/pii/S0925753517306409 [in English].

Received by Editorial Board: 16.03.2021

Suggested Citation:

Nechyporuk, M., Pavlikov, V., Ivanović, A., Filipenko, N. (2021). Forensic Science Posibilities Within The Framework Of Criminal Proceedings While Aviation Accidents (Review Article). Archives of Criminology and Forensic Sciences. 1(3). 56-64. DOI: https://doi.org/10.32353/acfs.3.2021.05 